Valóságos könyvtár - könyvtári valóság. Könyvtár- és információtudományi tanulmányok 2020. Szerk. Kiszl Péter, Boda Gáborné Köntös Nelli.

Budapest, ELTE BTK Könyvtár- és Információtudományi Intézet. 2021. 27-35.

\title{
EGY RÉGÉSZ KÖNYVTÁRAI
}

\author{
VIDA TIVADAR \\ ELTE BTK Régészettudományi Intézet, intézetigazgató, \\ egyetemi tanár, az MTA doktora
}

\section{TARTALMI ÖSSZEFOGLALÓ}

A régész feltáró munkája során a valaha élt emberek életének minden olyan megnyilvánulásával szembesül, amely egykor fizikai nyomot hagyott a föld alatt vagy a föld felett. A feldolgozó és elemző munka ugyanakkor a tárgyi világon túli összefüggések felismerésére, a politikai, gazdasági, kulturális vagy vallási rendszer rekonstrukciójára irányul. A leletanyag és a régészeti jelenségek „párhuzamainak” keresése ma is a könyvtárakban zajlik, ahol a régi könyvekben, tanulmányokban ugyanúgy lapulhatnak alapvető információk, mint a legújabbakban. Ezért a régész számára a könyvtár nemcsak a legfrissebb elméleti és módszertani múveket tároló hely, hanem adattár is, a módszeres kutatások kezdete, a XIX. század közepe óta közölt, el nem évülő alaprajzok, dokumentumok, lelet- vagy feliratkorpuszok és kézikönyvek tára. Az alapfeldolgozás, a rendszerezés bátran elvégezhető a múzeumi, egyetemi és kutatóintézeti szakkönyvtárakban, ahol a könyvek jó esetben korszak, téma és földrajzi egység szerint kereshetők. Az egyetemes történeti vagy kultúrtörténeti kérdéseket is felvető különleges leletek és rejtélyek a régészt kalandos hazai és külföldi könyvtári barangolásra késztetik.

\section{$* * *$}

Tízéves voltam, amikor elhatároztam, hogy régész szeretnék lenni, és attól kezdve tudatosan kerestem és választottam régészeti és történeti olvasmányokat. Kezdetben meg kellett elégednem szülőfalum, a dunántúli Marcal folyó mentén fekvő Külsővat nyújtotta lehetőségekkel, az iskolai és a falusi könyvtárral. Szüleim gondosan megvásárolták gyermekeiknek az Új Magyar Lexikont, s én még ma is őrzöm a kötetek régészeti címszavai alapján nyaranta szorgosan készített jegyzeteimet. Később talán ez az emlék is ösztönzött arra, hogy a 2000-es években magam is részt vegyek a Magyar Nagylexikon egyes kora középkori régészeti szócikkeinek elkészítésében. Pályaválasztásom részben édesapámnak köszönhetem, aki a mezőgazdasági munkák ellenőrzése során kiskoromtól fogva rendszeresen magával vitt a falu határába, és elmesélte, hogy hol, milyen régészeti emlékek kerültek elő: neolit balták, bronzkori urnák, Árpád-kori cserepek vagy török kori patkók. Jól ismerte a régészeti leleteket, mert a 60-as években sok helyi információval segítette a Magyarország Régészeti Topográfiája program keretében a faluban terepbejárást végző régészeket, a veszprémi Laczkó Dezső Múzeum és a Magyar Tudományos Akadémia (MTA) Régészeti Intézetének munkatársait. Akkor még nem sejthette, hogy 


\section{VIDA TIVADAR}

húsz év múlva fia is ez utóbbi intézménynek lesz kutatója. Külsővat szerencsés falu volt a 60-70-es években, mert a helyi tanárokból, tisztviselőkből és vezetőkből kivételes lokálpatrióta közösség formálódott, akik kiszorították a megyétől vagy járástól küldött „bőrkabátosokat”, és lelkesen kutatták a különféle régészeti, néprajzi és más honismereti emlékeket, és többek között (szabálytalanul) magánásatást is szerveztek egy római villa területén. A falu terein emlékműveket állítottak a haza függetlenségéért harcoló Zrínyi Miklósnak, Bocskai Istvánnak és Rákóczii Ferencnek, az ő nevüket viselték az utcák, az iskola és a Tsz is, így nem jutott egyetlen hely sem a kor kedvelt mozgalmárainak és ideológusainak. Nem is tudom, hogy volt-e még helység Magyarországon, ahol ezt sikerült megvalósítani. Később a celldömölki Berzssenyi Dániel Gimnázium több lelkiismeretes és elmélyült tanára támogatta és segítette pályaválasztásom. Itt a gimnáziumi könyvtár mellett még a városi könyvtárban tájékozódhattam, ahol az órák után bejáróként az autóbusz indulásáig olvasásra használtam ki az időt, és még éppen meghallgathattam egy bakelitlemez mindkét oldalát.

Rövid hódmezővásárhelyi katonáskodás után - ahol hosszabb lélegzetvételt igénylő művek, mint például Széchenyi Naploja elolvasására is szakíthattam időt - 1981ben megkezdtem tanulmányaimat az Eötvös Loránd Tudományegyetemen (ELTE) magyartörténelem, majd a második évtől régészet-történelem szakon. Ekkor Lász̧ló Gyula már nem tanított, s a népvándorlás kori régészetet Bóna István, a provinciális római régészetet pedig Mócsy András oktatta. Mindketten inspiráló, nagy formátumú tudós egyéniségek voltak, akik saját szakterületükön nemcsak a hazai, hanem az európai, Krisztus utáni első évezred régészetére is nagy hatással voltak. Mindezt az is bizonyította számunkra, hogy legalább ők, kiterjedt nemzetközi kapcsolataikon keresztül meg tudták szerezni a Kárpát-medencei régészet szempontjából alapvetően fontos könyveket (amelyek különben nem jutottak volna be az országba), és ezek ugyan a magánkönyvtárukba kerültek, de azokat szívesen kölcsön is adták nekünk. Akkoriban anyagi források hiányában sokszor a drága könyvek megszerzésének egyetlen módja volt a szakmai ismertetés, a recenzió elkészítése. Nem véletlen, hogy e nagy tudósok bibliográfiáiban is tekintélyes részt töltenek ki az értő könyvismertetések. E hagyományt folytatta később Szabó Miklós professzor is, akinek nagy olvasottságot és biztos értékítéletet mutató ismertetései fontos eligazodást nyújtottak az ókori régészet hazai múvelóinek, nemcsak az egyetemi hallgatóknak, hanem a kutatóknak is. Mócsy András akadémikus ősnyomtatványokat is tartalmazó könyvtára azonban a méltatlan örökösök, alkalmatlan tárgyalók hibájából és kollaboráns antikváriumok révén szétszóródott (néhány könyvet könyvtárainknak, magánszemélyeknek sikerült jó pénzért visszavásárolni). Bóna István könyvei azonban, szerencsére, egyetemi könyvtárakba kerültek, a népvándorlás kori kötetek fontos hiányokat pótoltak az ELTE Régészettudományi Intézetének könyvtárában, az őskori könyvek pedig a Pázmány Péter Katolikus Egyetem régészeihez jutottak.

A 80-as évek elején az ELTE BTK Régészeti Tanszékének könyvtára jól ápolt, gondozott kis gyűjtemény volt, sok muzeális és a XIX., illetve a XX. század első feléből 
származó kötettel, amelyek a korábbi professzorok (Alföldi András, Torma Károly, Tompa Ferenc) révén kerültek oda. Amint a könyvtár kinőtte a háború előtti fából készült bútorokat, a nem éppen esztétikus fém polcokkal kellett minden helyet kihasználni. A tanszéki könyvtár azonban akkoriban inkább oktató-, mint hallgatóbarát volt, mert a hallgatók közvetlenül nem férhettek a könyvekhez, a könyvtár rendszerét is csak a könyvtárosok és a tanárok ismerték, s a diákok katalóguscédulákon tájékozódhattak benne (amikor már végeztem, ígéretet kaptam, hogy a nyári szünetben majd kedvemre egyedül végigböngészhetem a könyvtárat, s ez különleges privilégiumnak számított, de sajnos nem került rá sor). Ennél is nagyobb nehézséget jelentett azonban a rövid nyitvatartás és a szűk hely. Éppen ezért általában a Magyar Nemzeti Múzeum Központi Könyvtáraban tanultunk, és készültünk a vizsgáinkra. A csodaszép klasszicista épületben a régészeti könyvtár (elkülönülve az akkor még a múzeumban székelő Széchényi Könyvtártól) a harmadik emeleten reggel 8-tól este 18 óráig nyitva volt. Ma már elképzelhetetlennek tűnik, de mi akkoriban teljesen kihasználtuk a nyitvatartási időt, hiszen még nem volt fénymásoló, szkenner, okostelefon, s mivel a régészet vizuális tudomány, ezért mi alaprajzokat, temetőtérképeket, leleteket rajzoltunk át „csőtollal” pauszpapírra, vagy indigós másolóval papírlapokra. Szenvedélyes könyvtári gyűjtőmunkánk során sorra jegyzeteltük ki a tanulmányokat, másoltuk ki az illusztrációkat, miközben tavasszal és kora ôsszel a nyitott ablakon át a múzeum mögött álló Esterházy-palota Márványterméből a rádió zenekara próbáinak beszűrődő dallamait hallgathattuk. A hosszú együttlét során jó kapcsolat alakult ki a könyvtárosokkal, Gézával és Misivel, és az elszántabbak elérték, hogy kedvükre szabadon kalandozhassanak a könyvtár többszintű raktárában (és ezzel kíméljék a fáradt könyvtárosokat a sok kilónyi könyv ide-oda cipelésétől). Külön élményt jelentett, hogy itt együtt olvashattunk az ismert múzeumi szakemberekkel, néha tanárainkkal, s ha merszünk volt, akár konzultálhattunk is velük. Akkoriban a könyvtár szombaton is nyitva volt, ma hetenként két nap is zárva van.

Egyetemi éveim alatt, történelem és eleinte magyar szakosként, jól használhattam a Kari Olvasó könyvtárát, de szívesebben jártam az elegáns Országgyülési Könyvtárba, az Egyetemi Könyvtárba vagy az MTA Könyvtárába. Ehhez az időszakhoz kötődnek különös oroszországi könyvtári élményeim, mert 1984 téli szemeszterében a Leningrádi Allami

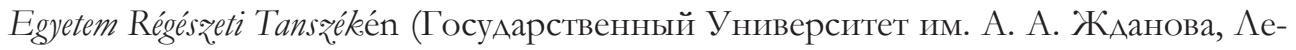
нинграА) tanultam. Az eurázsiai régészet kutatására készülő régészhallgatóként vállalkoztam az útra, mint korábban sok társam (Borby Lász̨ló, Somogyi Péter), hiszen akkoriban nyugatra még alig juthattunk el. Leningrádban, a mai Szentpéterváron, lassan belejöttem az orosz szakirodalom olvasásába, hetente egy napot töltöttem az Ermitázsban, neves régészekkel konzultálhattam, akikkel a kapcsolatot később is tartottam (A. Ivanov, $O$. Scseglova). Rendszeresen látogattam a Nagy Péter által építtetett Tizenkét Kollégium történelmi épületében lévő egyetemi könyvtárat, valamint az Orosz Tudományos Akadémia Régészeti Intézetének, az Ermitázs melletti pompás Mihajlovszkij palotában elhelyezkedő, Néva parti könyvtárát (Ново-Михайловский дворец, Аворцовая набережная). Annak 


\section{VIDA TIVADAR}

ellenére, hogy ezeket a könyvtárakat egységesen betöltötte a könyvek felejthetetlen (talán a korabeli nyomdatechnikának köszönhető) enyves illata, mégis lenyűgözőek voltak a hatalmas birodalom nagy földrajzi és kulturális régióinak (pl. Kaukázus, Ural, Szibéria, Közép- és Belső-Ázsia) gazdag régészeti szakirodalmával, a legújabb ásatások anyagainak közleményeivel és a kiterjedt nemzetközi cserekapcsolatokat tükröző könyvállománnyal. Mivel még egyetemistaként bekapcsolódhattam az MTA Régészeti Intézetének Bálint Csanád által vezetett telepkutatási programjába, és ezen belül az avar és a sztyeppei kerámia kutatása volt a feladatom, később jó hasznát vettem a leningrádi szemeszternek, nemcsak a könyvtárazásnak, hanem a személyes kapcsolatoknak is.

Az MTA Régészeti Intézetének a könyvtárát régészhallgatók kedden és szerdán használhatták. Ez a könyvtár akkor anyagilag viszonylag jobb helyzetben volt, több hagyatékot is megörökölt és emellett a sok jól képzett, nemzetközi hírű kutatónak köszönhetően számos, az európai régészet tekintetében alapvetően fontos kötet jutott el ide. E kutatói könyvtár legfontosabb csereeszköze az intézet évkönyve (a Mitteilungen..., Antaeus) ${ }^{1}$ volt, akkor is és ma is mintegy 260 európai és tengeren túli kutatóintézeti, egyetemi, múzeumi tudományos múhelyhez jutott el. A viszonzásként kapott kötetek páratlan tájékozódási lehetőséget nyújtottak és nyújtanak a hazai régészeknek a legújabb leletekrôl és kutatási irányokról. A legfrissebb elméleti szakirodalom beszerzése ekkor nehézkes volt, több fontos mú a személyes kapcsolatoknak köszönhetően jutott be az országba, de gyakran az MTA Központi Könyvtáraban a vélt hiányok ellenére is meglepő felfedezéseket lehetett tenni.

Kezdő régészként az a szerencse ért 1989 nyarán, hogy a budakalászi avar kori temető ásatásán előkerült életem régészeti lelete, egy vadászjelenetekkel, ezüst és vörösréz berakással díszített, dombormúves kora bizánci sárgaréz korsó. Habár provinciális római koros régészetet is végeztem, a késő antik múvészet és toreutika nem tartozott a szűkebb szakterületemhez, mégis a késő ókori világban a mai napig páratlan lelet feldolgozása olyan tudományos kihívást jelentett, amiért „érdemes a vízbe ugrani” - bíztatott erre Szabó Mikelós professzor. Ettől kezdve lázas kutatásba fogtam, de a vadászjelenetekkel díszített késő antik korsónak a mai napig nem találtam meg a pontos párhuzamát.

A következó évben eljutottam Londonba, ahol rövid ideig a The Warburg Institute könyvtárában kutathattam. E híres könyvtárat $A b y$ Warburg, a neves múvészet- és kultúrtörténész hozta létre Hamburgban (Kulturwissenschaftliche Bibliothek Warburg), aki alapvetôen az antik kultúrának a középkori és a kora újkori Európára gyakorolt hatását vizsgálta. E könyvtárat 1933-ban menekítették ki a hitleri Németországból és a háború után illesztették a University of London szervezetébe. A könyvtárban alapvetően tematikus rendben, négy emeleten sorakoztak a könyvek, és én valójában itt értettem meg, milyen nagy kihívást jelent a budakalászi korsó feldolgozása, de egyben itt éreztem meg azt is, ha ehhez hasonlóan gazdag, jól felszerelt könyvtárakban kutathatok, akkor elkészíthetem a korsó formájának, ikonográfiai kapcsolatainak feltérképezését, múvészeti és kultúrtörténeti jelentőségének meghatározását. Minderre 1993-ban nyílt újabb lehetőségem, amikor DAAD (Deutscher Akademischer Austauschdienst) ösztöndíjjal egy 
évre a müncheni Ludwig Maximilian Universitätre kerültem. Itt az Intézet titkárnőjétől, a legnagyobb meglepetésemre, az első nap megkaptam a régészeti könyvtár kulcsait, ahová bármikor, éjjel is és hétvégén is bemehettem. Ma már nehéz elmagyarázni azt a felfokozott érzést, ami akkor elfogott a könyvtár gazdagsága és a munkakörülmények szabadságát látva, valósággal lázban égve kezdtem a munkához. A könyvtárban a PhD hallgatókhoz hasonlóan egy barátságos ablakmélyedésben saját asztalt kaptam, amelyen körülbelül 15 könyvből álló kollekciót állíthattam fel. Ezen az ideális kutatóhelyen értettem meg, hogy nemcsak egy gazdagabb, hanem egy emberközpontú világba is érkeztem. A könyvtárban hely szerint rendezve külön voltak a múzeumi katalógusok, a konferenciakötetek, név szerint a Festschriftek, elkülönülten a kiválasztott tematikus egységek (pl. elméleti régészet) és a monográfiák földrajzi és időrendi (őskor, ókor, középkor) felosztásban. Ennél aligha lehetett többet kívánni. Mivel a müncheni egyetem régész-oktatóinak érdeklődése hagyományosan, szinte minden korszakban a dél- és közép-európai térség felé irányult, e tudományos múhely könyvtárát is ennek a célnak megfelelően fejlesztették, így kitűnő szakirodalmat találtam az 1600 síros budakalászi VI-VIII. századi temető Meroving és mediterrán-bizánci leletanyagának kutatásához.

A budakalászi késő antik korsó témájában azonban elsősorban az Institut für Klassische Archäologie könyvtárában találtam bőséges szakirodalmat. A világ egyik leggazdagabb klasszika archeológiai könyvtárában legelőször a hatalmas topográfiai terem nyűgözött le, amelyben körben a falon hosszú métereken, katonás rendben sorakoztak az ismert európai és mediterráneumi antik lelőhelyek monográfiái, sok-sok ezer kötet Apameatól Zaldapaig, de közöttük volt Savaria és Aquincum is. Ezen kívül külön termekben, tematikus rendben voltak az ókori világ anyagi és szellemi kultúrájának kérdéseit tárgyaló könyvek (pl. források, vallás, rítus, mozaikok, épületek, gemmák, üvegek). Módszertani segítséget a budakalászi korsó feldolgozásához az Institut für Byzantinistik múvészettörténész professzorától Johannes Deckerstől kaptam, akinek ezért ma is nagy hálával tartozom.

A késő római és a kora bizánci időszakban a vadászat ábrázolása igen kedvelt téma volt mind a magán, mind pedig a közszférához tartozó épületekben: villák, paloták, templomok mozaikjain vagy festményein, de megjelent a toreutikában vagy a kismúvészetekben is. A késő antikvitás idején a vadászatábrázolások azért jöttek divatba, mert a megrendelő, a tulajdonos életformájára utaltak, bizonyítva, hogy ő olyan vagyonos személy, aki vadászattal múlatja idejét, vagy képes költséges cirkuszi állatviadalok (venatio) rendezésére. A vadász személye alkalmas volt a győztes úr, az erényei, ügyessége, ereje és intelligenciája segítségével a természet erőin, a halálon győzedelmeskedő ember megjelenítésére. A vadász nem egy hétköznapi ember, hanem egy hős, egy hérosz. A sikeres vadász példájából bármely szemlélő erôt meríthetett és így a vadászat, mint szerencsét hozó jelkép válhatott a késő antik korban kedvelt díszítőelemmé. A vadászjelenetek feltûntek az ókeresztény vallási szimbolika részeként is. A budakalászi kora bizánci korsóról írott munkám képezte 2012-ben habilitációs dolgozatomat, amely 2016-ban, illetve 2017-ben monografikus formában is megjelent. ${ }^{2}$ 


\section{VIDA TIVADAR}

Az Institut für Klassische Archäologienek otthont adó hatalmas épület másik végében van az európai művészettörténet egyik legjelentősebb könyvtára, a Zentralinstitut für Kunstgeschichte, hangsúlyozottan gazdag középkori anyaggal. Ebbe, a Königsplatzon található páratlan könyvtárba, Bogyay Tamás történész vezetett be, aki 1945-ben feleségével, Halliársæky Mimivel a budapesti Szépmúvészeti Múzeum mútárgyszállítmánya egyik kísérőjeként érkezett Bajorországba. Az amerikai hadsereg a Németország déli részén elkallódott, elrablott műkincsek összegyűjtésére és a tulajdonosok felkutatására az egykori NSDAP (Nationalsozialistische Deutsche Arbeiterpartei) székházban hozott létre gyújtőhelyet (Munich Central Collecting Point). Ennek az intézménynek lett kezdetben a szakértője Bogyay Tamás is, és az itt kialakult könyvtár és kutatóhely lett a Zentralinstitut alapja, amelynek múködtetését később a bajor állam vette át. Bogyay Tamás 1962-ben alapítója és első igazgatója lett a tudományos és kulturális kérdésekkel foglalkozó Müncheni Magyar Intézetnek.

Az állami könyvtárak mellett mély benyomást tettek rám a professzori magánkönyvtárak (pl. Volker Bierbrauer vagy Georg Kossack könyvtárai). Makkay János révén eljutottam a neves etnológushoz, az 1956 után Németországba került Vajda László egyetemi tanárhoz, akinél rendszeres látogatásaim során nemcsak a müncheni életformát és a bajor tudományos élet múködését ismerhettem meg, hanem egy kivételes tudós egyéniséget is, hiszen Vajda professzor érdeklődése térben és időben rendkívül széles körű volt, az ős- és ókortörténettől a mai társadalmi és politikai problémákig ívelt. Vajda Lász̧ló folyamatosan dolgozott, közel egymillió kis cédulát hagyott a müncheni Néprajzi Múzeumra, mert számára - mint generációja sok képviselőjének is - a tudomány volt mindennek a fö értelme: mi „nem a tudományért, hanem a tudomány által élünk” - mondta egy életrajzi interjúban. Vajda László a komparatív etnológiai kutató módszer képviselője (és hazai meghonosítója volt), több szobára terjedő könyvtárában a személyes érdeklődését tükröző, sokféle diszciplínához tartozó kötetek - etnológia, vallástörténet, vallástudomány, klasszika-filológia, régészet, az ős- és ókortörténet, folklorisztika, nyelvészet, művészettörténet, zenetörténet - mutatták az emberiség kultúrtörténetét vizsgáló nagy tudós tág horizontját. Vajda László neve a müncheni régészek számára is fogalom volt, könyvtára a látogatók előtt éjjel nappal nyitva állt, s generációk tanultak tôle komparatív szemléletet és gondolkodásmódot. Több ezer kötetes könyvtárát a müncheni Néprajzi Múzeumra hagyta azzal, az egyetemi viszonyokra nem igazán hízelgő kitétellel, hogy a duplumok nem kerülhetnek tanszéki könyvtárba.

Ilyen hazai és külhoni könyvtári előzmények után kerültem 1994 tavaszán Frankfurtba a Német Régészeti Intézet keretében múködő Römisch-Germanische Komission (RGK) könyvtárába, amely számomra a következô évtizedekre a régészeti kutatás szentélyévé vált. Akkoriban egy Münchenben elkezdett speciális témán dolgoztam és felmerült, hogy leginkább itt találhatom meg a tanulmány befejezéséhez még szükséges szakirodalmat. Az antik eredetú amulettkapszulák kora középkori továbbélésének formáit kutattam, mert a fa, bronz vagy ezüst szelencék az előkelő nők hagyatékában részben pogány módra növényi és más amuletteket tartalmaztak, részben pedig keresztény jelképeket 
viseltek. A jelenség egyértelmúen mutatta a pogány hagyományok krisztianizálódását. A Römisch-Germanische Komission tematikus könyvtára elsősorban Európa ős- és korai történetére, valamint a provinciális római régészetre specializálódott, és páratlan tudományos eszmecserét tett lehetővé azáltal, hogy vendégszobáiban nagyvonalúan fogadta Európa és a világ kutatóit, hiszen a német precizitással megszervezett könyvtár közel 200000 kötetével jobb kutatási lehetőséget biztosított, mint a nemzeti könyvtárak. A külügyminisztériumhoz tartozó Deutsches Archäologisches Institut a XIX. század második felében hozta létre a puha kulturális expanziót megtestesítő kül- és belföldön működő régészeti intézeteit. (1929-ben egyetemünk professzora, Alföldi András az RGK tudományos tanácsának is tagja volt, ma pedig Bánffy Eszter régész, az intézmény igazgatónője.) Az intézmény vendégkönyveiben a II. világháború utáni régészeti kutatás vezető személyiségeinek neveit találhatjuk meg. Elkészült tanulmányomat a szerkesztő, Uta von Freeden, felvette az intézmény évkönyvébe, ${ }^{3}$ és ezt követően igyekeztem évenként több hetet is ezen a kutatóhelyen eltölteni. Jó együttmúködés alakult ki, és ennek köszönhetően 2005-2010 között egy magyar-német közös projektben tártuk fel a szóládi langobard kori temetőt, amelynek ezt követően kezdődött el bioarchaeológiai (DNS) és izotópkémiai vizsgálata.

1997-ben a mediterrán tájakon kaptam kutatási lehetőséget, amikor az „Olympia in der römischen Kaiserzeit und der Spätantike” címú DFG-Projekt nemzetközi kutatócsoportjának tagjaként Thomas Völling kollégámmal és barátommal együtt feldolgozhattam az olympiai hamvasztásos szláv temetô leletanyagát. A bizánci források bőségesen tudósítanak a szlávok és avarok balkáni pusztításairól Olympiában. A Kronosz-dombtól északra fekvô terület a VII. század második negyedétől a VIII. század végéig, egy szláv népcsoport temetkezőhelye

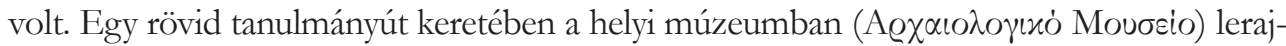
zoltam a leleteket, majd ismét hasznát vehettem a szentpétervári könyvtárazásoknak, mert a leletanyag és a temetkezési szokások elemzésével sikerült feltárni e betelepült közösség kelet-európai kulturális kapcsolatait. A Peloponnészoszon és a Mediterráneumban előke-

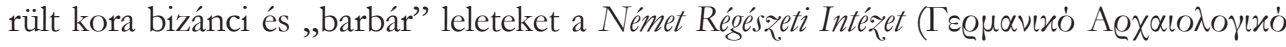

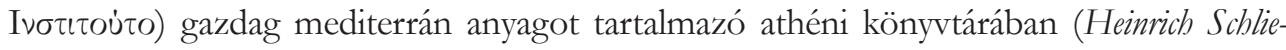
mann egykori lakóházában) kutathattam, így e különös olympiai leletanyagot sikerült beilleszteni Görögország „sötét korának” (dark age) történetébe. ${ }^{4}$

Ettől kezdve a kialakult kapcsolatrendszeremnek köszönhetően és a megismert könyvtárak tematikus súlypontjainak megfelelően, külföldi útjaimat, a konferencia-részvételeket, a projektmegbeszéléseket igyekeztem összekötni néhány hetes könyvtárazással. Akkor kikapcsolhattam a telefont, s a jól strukturált, szabadpolcos könyvtárakban sokkal hatékonyabban tudtam kutatni, és megnyugtatóbban tudtam egy-egy kutatási témát lezárni. Közben a hazai kutatói könyvtárak is fokozatosan gyarapodtak, de szervezetükben nem következett be változás, maradt a könyvek beszerzési időponton és méreteken alapuló mechanikus elhelyezése, a szűk „hivatali” nyitvatartási idő, vagyis itthon a mentalitás a régi maradt. 


\section{VIDA TIVADAR}

Egyetlen kivételt jelentett az ELTE Régészettudományi Intézete könyvtárának, Raczky Pál és Kalla Gábor kezdeményezésére, 2002-ben bekövetkezett átalakítása. Ők több hónapos munkával kidolgozták egy szabadpolcos, kutató- és hallgatóbarát régészeti könyvtár, nyugaton már legtöbbünk által megtapasztalt modelljét, s ezen elméleti terv alapján egy téli vizsgaidőszakban az intézet oktatói és $\mathrm{PhD}$ hallgatói társadalmi munkában átrendezték és újra feliratozták a könyvállományt. A gyakorlati munkát jelentôsen megkönnyítette, hogy ekkor már rendelkezésre állt a könyvek digitális adatbázisa, amelyet az egyetemi hallgatók, PhD hallgatók az 1990-es évek közepétől folyamatosan készítettek. A múvek leírása ugyan nem minden tekintetben felel meg a szigorú könyvtári elvárásoknak, de legalább megvalósult a kutatást segítő, jól működő kereshető rendszer (a könyvtár állománya ma több mint 40000 tétel). A könyvtár termeiben azóta az állomány időrendi felosztásban található meg, azon belül pedig topográfiai és tematikus tagolásban. E bátor tett további változásokat eredményezett. Mindenekelőtt sikerült biztosítani az esztétikus elhelyezést, a korszerú tereket és polcokat, a könyvtárat fénymásolóval, számítógéppel, később szkennerrel szerelték fel. Az új rendszer megkövetelte a demokratikus könyvtárhasználatot, így visszakerültek helyükre a tanári szobákban évtizedek óta lapuló monográfiák és folyóiratok. Megszűnt a kölcsönzés, ugyanakkor a könyvtár nyitvatartása este 19 óráig meghosszabbodott, 16 óra után a PhD hallgatók látják el a felügyeletet. Ettôl kezdve öröm volt látni a könyvtárban beindult pezsgó életet. A fizikai kapcsolat a könyvekkel nemcsak otthonos érzetet adott, hanem visszahatott a kutatás minőségére, így a könyvtár végre betöltötte azt a funkcióját, amire rendeltetett, a hallgatók és oktatók számára valódi közösségi tér lett, ahol rendszeressé váltak az előadások, a konferenciák és szemináriumok. További hatalmas eredmény, hogy Bartus Dávid a hallgatóival feldolgozta az intézet összes folyóiratát és tanulmánykötetét. E tanulmányokat feltáró adatbázis mára már közel 150000 tételből áll, online elérhető, amit a tapasztalatok szerint külföldi kollégák is felkeresnek szakirodalom gyújtésére.

A könyvtár az utóbbi években jelentős hagyatékokkal gyarapodott, Alföldy Géza provinciális római-epigráfiai, Eva Strommegger őskori elö-ázsiai és Kalicz. Nándor őskori könyveket tartalmazó könyvtáraival. A sok ezer kötet elhelyezése ma már egyre nagyobb nehézséget jelent és már-már aggodalommal tekintünk több megígért újabb hagyatékra.

Ám közben, a digitalizáció rohamos előrehaladásával, a könyvtárhasználat új formái alakulnak ki, hiszen újabban megnôtt az online elérhető régészeti szakirodalom jelentősége. Miközben a könyvtárainkban a XX. század második felében keletkezett jelentős hiányokat, a 90-es évektől a külföldi tanulmányutakon szerzett sok-sok kilónyi fénymásolattal igyekeztünk pótolni, mára ez a helyzet is gyökeresen megváltozott, mert napjainkban a meghatározó találkozások már interneten zajlanak, ahol szinte nincs beszerezhetetlen publikáció, s akárki őrizheti otthon egy winchesteren egy téma teljes szakirodalmát. Mindez azonban a könyvtáraknak, mint közösségi helyeknek a jelentőségét még inkább kiemeli, mert azok remélhetőleg nemcsak a szkennelés és a fotózás, 
hanem továbbra is a személyes találkozások, az eszme- és információcserék, a békés és hatékony alkotómunka helyszínei maradnak.

\section{Jegyzetek és irodalom}

1. Mitteilungen des Archäologischen Instituts der Ungarischen Akademie der Wissenschaften. Budapest, MTA Régészeti Intézet, 1970-1985.; Antaeus: Communicationes ex Instituto Academiae Scientiarum Hungaricae. Budapest, MTA Régészeti Intézet, 1986-

2. VIDA, Tivadar: Late antique metal vessels in the Carpathian Basin: luxury and power in the Early Middle Ages. Budapest, Archaeolingua, 2016.; Die frühbyzantinische Messingkanne mit Jagdszenen von Budakalász (Ungarn). Budapest, Institut für Archäologie Forschungszentrum für Humanwissenschaften Ungarische Akademie der Wissenschaften, 2017.

3. VIDA, Tivadar: Frühmittelalterliche Scheiben- und kugelförmige Amulettkapsel zwischen Kaukasus, Kastilien und Picardie. = Bericht der Römisch-Germanischen Kommission, Bd. 76. 1995. 221-292. p.

4. VIDA, Tivadar - VÖLLING, Thomas: Das slawische Brandgräberfeld von Olympia. Rahden, Verlag Marie Leidorf, 2000.

Vida Tivadar - régész, egyetemi tanár, az MTA doktora. Az ELTE BTK Régészettudományi intézetének igazgatója, a Népvándorlás kori és Középkori Tanszék vezetője. Kutatási területe a Kárpát-medence helyi és betelepült népeinek kulturális és társadalmi viszonyai, európai, mediterrán és eurázsiai kapcsolatrendszere a Kr. u. I. évezredben. Monográfiája jelent meg az avar kori edényművességrôl, az olympiai szláv temetőről és a budakalászi korsó kapcsán a késő antik toreutikáról. Ásatásokat folytatott a budakalászi avar és a szóládi langobard temetőkben. Újabban bioarchaeológiai kutatócsoportok munkáját irányítja, a HistoGenes ERC Synergy Grant egyik témavezetője. Több régészeti folyóirat szerkesztőbizottságának tagja, a népvándorlás kori leletkorpuszok társkiadója. DAAD- és Humboldt-ösztöndíjas volt, a Német Régészeti Intézet levelező tagja. ORCID: 0000-0002-0588-1906 